\title{
PLANT PARASITIC NEMATODES IN NEW ZEALAND CEREALS
}

\author{
KAREN KNIGHT
}

Plant Protection Centre, MAF Quality Management, PO Box 24, Lincoln, NZ.

\begin{abstract}
A nationwide survey ofpests and diseases ofcereals and selected grass seed crops was conductedbetween September 1995 andMarch 1996. The aims ofthe surveywere to disclose any new pests and diseases present in the country and to map these and preexisting diseases. Information gathered in this survey is used in negotiations for overseas market access. All cereal growing regions in New Zealand were surveyed by crop inspection and laboratory examination of selected plants and soil. Nematodes were extracted from soil samples using a Whitehead tray. This survey revealed cereal root knot nematode, Meloidogyne naasi (Franklin 1965), in three new regions (Mid Canterbury, South Canterbury and Southland), and the lesion nematode Pratylenchus thornei (Slier \& Allen 1953) to be widespread in North, Mid and South Canterbury on all graminaceous crops surveyed. The significance of these nematodes in New Zealand conditions has not been established, but $M$. naasi has been reported to cause total crop losses in Europe, and $P$. thornei causes up to 85\% crop loss of cereals in Australia. Farmer estimates indicate $\$ 800 /$ ha losses are already occurring in South Canterbury. Subsequent to this survey, M. naasi was observed feeding and reproducing on carrot roots. This is a new host record for New Zealand.
\end{abstract}

\section{THE CONTROL OF APHIDS IN POTATOES WITH PYMETROZINE}

\author{
G. FOLLAS
}

\section{Ciba-Geigy New Zealand Limited, P 0 Box 1044, Hastings}

A single randomised complete block trial was carried out in the Hawkes Bay on the potato cultivar Rua in the December-January period. Two applications of pymetrozine at 50, 100 and 200 $\mathrm{g} / \mathrm{ha}$ were made at a 21 day interval compared with the standard methamidophos $480 \mathrm{~g} / \mathrm{ha}$ and an untreated. Assessments were made by counting the number of aphids/leaf on 50 leaves/plot at 6,14 and 21 days after treatment (dat). There was no difference in the efficacy of the insecticides against the two aphid species identified - potato aphid (Macrosiphum euphorbiae Thomas) and green peach aphid (Myzus persicae Sulzer). No insecticide gave a reduction in the number of alate aphids/leaf $(\mathrm{P}>0.05)$. All insecticides reduced the number of apterous aphids/leaf at all assessments compared with the untreated $(\mathrm{P}<0.01)$. Increasing the rate of pymetrozine from $50 \mathrm{~g}$ decreased the number of aphids/leaf $(\mathrm{P}<0.05) 14$ and 21 dat. The 100 and $200 \mathrm{~g} /$ ha rates of pymetrozine were equivalent in efficacy to methamidophos $(\mathrm{P}<0.01)$. Pymetrozine applied at $100 \mathrm{~g} / \mathrm{ha}$ showed a high level of efficacy against aphids in potatoes and is an 1PM compatible replacement for the OP insecticides. 